\title{
Epiphytic lichens of woodland habitats in the lower Ticino river valley and in the "Bosco Siro Negri" Integral Nature State Reserve (NW Italy)
}

\author{
Gabriele Gheza ${ }^{1,2}$, Juri Nascimbene ${ }^{1 *}$, Matteo Barcella ${ }^{2}$, Francesco Bracco ${ }^{2}$, \\ Silvia Assini ${ }^{2}$
}

\begin{abstract}
Epiphytic lichens were surveyed in the "Bosco Siro Negri" Integral Nature State Reserve (province of Pavia, Lombardy, NW Italy), which hosts a well-preserved fragment of oak-elm floodplain forest (Natura 2000 Habitat 91F0). The core woodland fragment hosted only four species on the tree boles, i.e. Lepraria finkii plus the forest specialists Coenogonium pineti, Diarthonis spadicea, and Opegrapha vermicellifera. An additional eight nitro- and photophytic species were recorded on the highest twigs of the canopy. The whole Reserve, including the neighbouring degraded woodlands and poplar plantations, hosted 27 epiphytic lichen taxa. The lower Ticino River valley between Vigevano and Pavia, in which the Reserve is located, was surveyed for epiphytic lichens in an additional 45 sites, including 15 well-preserved oak-elm/hornbeam woodlands (Habitat 91F0), 15 degraded broadleaved woodlands with high occurrence of black locust and 15 poplar plantations. Overall, 32 species were recorded. Well-preserved woodlands had a lower species richness, but they hosted forest specialists not occurring in the other two habitats. Graphis pulverulenta and Lecania cyrtellina are new to Lombardy. Anisomeridium polypori, Diarthonis spadicea, Lecanora expallens and Pseudoschismatomma rufescens are reported from Lombardy for the second time.
\end{abstract}

Keywords: floodplain forests, Habitat 91F0, Natura 2000 Network, plantations, river parks.

Riassunto - Licheni epifiti di habitat boschivi nella bassa valle del Ticino e nella Riserva Naturale Integrale Statale "Bosco Siro Negri" (Italia nordoccidentale).

Sono stati censiti i licheni epifiti presenti nella Riserva Naturale Integrale Statale "Bosco Siro Negri" (provincia di Pavia, Lombardia, Italia nordoccidentale), che ospita un frammento ben conservato di

${ }^{1}$ BIOME Lab, Dipartimento di Scienze Biologiche, Geologiche e Ambientali, Alma Mater Studiorum, Università di Bologna, Via Irnerio 42, I-40126 Bologna, Italia.

E-mail: gheza.gabriele@gmail.com

Sezione di Ecologia del Territorio, Dipartimento di Scienze della Terra e dell'Ambiente, Università degli Studi di Pavia, Via S. Epifanio 14, I-27100 Pavia, Italia.

E-mail: matteo.barcella@unipv.it francesco.bracco@unipv.it silviapaola.assini@unipv.it

* Corresponding author: juri.nascimbene@unibo.it

(C) 2022 Gabriele Gheza, Juri Nascimbene, Matteo Barcella, Francesco Bracco, Silvia Assini

Received for publication: 28 July 2021

Accepted for publication: 9 November 2021

Online publication: 20 October 2022 foresta alluvionale a dominanza di farnia e olmo (Natura 2000 Habitat 91F0). Il frammento centrale del bosco ospitava sui tronchi degli alberi solamente quattro specie, cioè Lepraria finkii più le specialiste forestali Coenogonium pineti, Diarthonis spadicea e Opegrapha vermicellifera. Altre otto specie nitrofitiche e fotofitiche sono state rilevate sui rami più alti della canopea. L'intera riserva, considerando anche i boschi degradati e i pioppeti limitrofi, ospitava 27 taxa di licheni epifiti. La bassa valle del Ticino tra Vigevano e Pavia, nella quale si trova la Riserva, è stata oggetto di un'indagine per la presenza di licheni epifiti in altri 45 siti, tra i quali 15 boschi ben conservati a dominanza di farnia, olmo e/o carpino bianco (Habitat 91F0), 15 boschi di latifoglie degradati con elevata presenza di robinia e 15 pioppeti. Complessivamente, sono state registrate 32 specie. I boschi ben conservati mostravano una ricchezza specifica inferiore, ma ospitavano specialiste forestali che non si trovavano negli altri due ambienti. Graphis pulverulenta e Lecania cyrtellina sono nuove per la Lombardia. Anisomeridium polypori, Diarthonis spadicea, Lecanora expallens e Pseudoschismatomma rufescens sono riportati dalla Lombardia per la seconda volta.

Parole chiave: foreste planiziali, Habitat 91F0, parchi fluviali, piantagioni, Rete Natura 2000.

\section{INTRODUCTION}

The Po Plain is the most human-impacted area of Italy: most of its surface is occupied by inhabited centers, industries, infrastructures and agricultural land, and the pollution levels are very high. All these factors contributed to a huge loss of natural habitats, which has impacted biodiversity for centuries. Due to its impacted and depleted condition, the Po Plain is the lichen-poorest area of Italy (Nimis, 1993, 2016). The Ticino River valley, which lies in the western part of the Po Plain, at the boundary between the regions of Lombardy and Piedmont, is a focal area for the protection and conservation of biodiversity: the entire river valley and the surrounding part of the plain are protected by two regional natural parks which have safeguarded natural habitats and wild species since the 1970 s.

Within this landscape, the Ticino River valley is also one of the few areas where lichenological research is going on since the $19^{\text {th }}$ century (Gheza et al., 2019): 123 taxa were reported in the checklist by Valcuvia Passadore et al. (2002a, 2002b) and additional 28 taxa were reported later (Gheza, 2018). However, the lower part of the river valley has been regarded as poorer in lichen species than the upper and middle parts (Valcuvia Passadore et al., 2002a, 2002b), and was also less investigated. 
Paradoxically, even if most of the efforts in studying lichens in the Ticino River valley and surroundings were focused on epiphytic lichens (Casarini et al., 1995; Zocchi et al., 1997; Roella, 1999; Furlanetto et al., 2000; Delucchi, 2005), woodlands were left almost completely overlooked. This happened because most studies applied the standardized method of "air quality biomonitoring" (ANPA 2001), which focused on trees outside dense woodlands. This resulted in a biased knowledge of epiphytic lichens, which did not take into account either the forest habitats with the highest naturalistic value, i.e. wellpreserved woodlands attributed to Natura 2000 Habitats 9160, 91E0 and 91F0, or those with the lowest value, i.e. artificial plantations of poplars or conifers. Therefore, in recent years we focused our research on Natura 2000 Habitat 91F0, which is the most widespread forest habitat of conservation value in the lower river valley (Perracino, 2010). The importance of this habitat is increased by the fact that it hosts the last relicts of the primeval floodplain forests of the Po Plain (Tomaselli \& Gentile, 1971; Sartori, 1984). A better understanding of the lichen biota of such relicts can likely improve our knowledge of the lichens occurring in the Po Plain before its anthropization.

Among the sites still hosting well-preserved woodland stands, outstanding is the "Bosco Siro Negri" Integral Nature State Reserve, donated by Giuseppe Negri to the University of Pavia in 1967. The Reserve is managed by the Department of Earth and Environmental Sciences, focusing on the maintenance of natural dynamics: no active management is allowed, in order to leave the woodland to its natural evolution (Tomaselli \& Gentile, 1971; Motta et al., 2009).

The main aim of this paper is to report the epiphytic lichen flora of the "Bosco Siro Negri" Reserve, since thorough lichenological studies have never been carried out in the site, in spite of its importance for the conservation of a primeval floodplain forest fragments. By extending to other sites in the surroundings of the river valley, this paper also provides deeper insights into the epiphytic lichen flora of the Natura 2000 Habitat 91F0 in the western Po Plain, also comparing it to epiphytic lichen biota of apparently similar habitats in the same area, namely degraded woodlands encroached by invasive species and poplar plantations.

\section{MATERIALS AND METHODS Study area}

The main study site was the "Bosco Siro Negri" Integral Nature State Reserve (Fig. 1), established in 1970 within the Lombardy Ticino Regional Park (Northern Italy), which covers about 11 hectares. Historically, the Reserve has always been forested, but formerly it was managed for wood production and used as a hunting reserve. Nevertheless, it currently represents one of the best-preserved relicts of the original floodplain forest once occurring along the Ticino River, and has remained unmanaged for over six decades. The last important human disturbances coincided with the two World Wars (1910-1920 and 19401960), while no logging has been carried out after the establishment of the Reserve in 1970 (Motta et al., 2009). The
Reserve, located on the western side of the Ticino River, protects a broadleaved oak-elm woodland attributed to the Natura 2000 Habitat 91F0 ("Riparian mixed forests of Quercus robur, Ulmus laevis and Ulmus minor, Fraxinus excelsior or Fraxinus angustifolia, along the great rivers (Ulmenion minoris)") in accordance with the Directive 92/43/EEC, and it is included in the EU Special Area of Conservation IT2080014 "Boschi Siro Negri e Moriano". The woodland is dense, structurally complex, and rich in biomass, as expected for a stand left unmanaged for decades. It is dominated by common oak (Quercus robur L.); other main tree species are elm (Ulmus minor Mill.), hornbeam (Carpinus betulus L.), poplar (Populus alba L.), and maple (Acer campestre L.); black locust (Robinia pseudoacacia L.) also occurs widely around the core area which hosts the best-preserved woodland fragment (Motta et al. 2009). The forested area was attributed to the association Polygonato multiflori-Quercetum roboris (Sartori, 1984). The mean annual precipitation is about $800 \mathrm{~mm}$ and the mean annual temperature is $13.6^{\circ} \mathrm{C}$ (Pavia weather station, $10 \mathrm{~km}$ from the study site). Floods occur in spring and/or autumn every 5-10 years (Castagneri et al., 2013). Except during such events, the groundwater level is around $-2.50 \mathrm{~m}$ in winter, while it reaches $-3.50 \mathrm{~m} \mathrm{du}-$ ring summer, being mainly influenced by the hydrometric levels of the river (unpubl. data). At the local scale, the surface is flat, but different irregularities are present, with depressions, reaching in some points $2 \mathrm{~m}$ in depth, opposed to bumps, resulting in an articulated general morphology (Tomaselli \& Gentile, 1971). The vascular flora and vegetation of the Reserve have been studied by Tomaselli \& Gentile (1971), Sartori (1984) and Motta et al. (2009), the bryophyte flora by Brusa (2014).

The study was extended to the whole lower part of the Ticino River course (Fig. 1), an area ranging from the Municipalities of Vigevano (western side) and Motta Visconti (eastern side) to that of Pavia (Provinces of Pavia and Milan). According to Castaldini et al. (2019), this area is located in the physiographic unit of the Holocene Floodplain, and Castiglioni and Pellegrini (2001) attributed it to a floodplain with surface lithology characterized mainly by gravel and sand. The bioclimate is temperate (Biondi \& Baldoni, 1994), with mean annual precipitation of about $900 \mathrm{~mm} /$ year (Navati et al., 1983), lower than those recorded along the middle and higher courses of the same river (1000 and $1400 \mathrm{~mm} /$ year, respectively). The vegetation of the lower Ticino River valley is framed in the hygrophilous Western plain geosigmetum (Verde et al., 2010), in which different plant communities are placed, from the active riverbed towards the surrounding plain. The woody vegetation farther from the active riverbed consists of communities dominated by oak and elm or hornbeam. Due to the intense human activity (agriculture, urbanization and alteration and banking of river course), the natural vegetation of the Ticino valley is fragmented, occurring only on limited surfaces. Particularly, the primeval natural oak-elm forests are drastically reduced and often replaced by poplar plantations and/or degraded groves dominated by invasive woody species (e.g. Robinia pseudoacacia). Natural oak-elm/oak-hornbeam woodlands attributed to the Natura 2000 Habitat 91F0 still persist, 
in this area, inside two EU Special Areas of Conservation: IT2080002 "Basso Corso e Sponde del Ticino" and IT2080014 "Boschi Siro Negri e Moriano".

\section{Surveyed sites}

The "Bosco Siro Negri" Reserve was fully explored in order to obtain a complete list of epiphytic lichens. Three habitat types were considered separately: (1) the core woodland area, with the well-preserved fragment of riparian oak-elm forest (UTM WGS84 32T 504530.5006418, 62-68 $\mathrm{m})$; (2) the surrounding woodlands, with a poorer environmental quality and invaded by black locust (UTM WGS 84 32T 504667.5006116-504035.5005298, 63-65 m); (3) the poplar plantations nearest to the core area (UTM WGS84 32T 504105.5006285-503947.5005620, 63-64 m).

For the study of the epiphytic lichen flora of woodlands and plantations, 45 sites were selected in the lower part of the Ticino River valley, between Vigevano and the confluence with the river Po south of Pavia (Tab. 1, Fig. 1). The conceptual setting of this wider sampling was the same applied in the "Bosco Siro Negri" Reserve: epiphytic lichens were sampled in (1) broadleaved oak-hornbeam or oak-elm woodlands with good ecological continuity attributed to Habitat 91F0, (2) degraded broadleaved woodlands with high occurrence of black locust, and (3) poplar plantations.

\section{Lichen sampling}

In the "Bosco Siro Negri" Reserve the core woodland area was intensively explored and the trunks of about 100 trees were surveyed from the ground level up to $2.5 \mathrm{~m}$, but also twigs and branches fallen from the canopy were collected in order to obtain information on the differences between the lichen biota occurring on trunks in the understory and those of tree crowns. In the other two habitat types, lichens were surveyed on the trunks and main branches of trees located along the main trails. Every tree species in the three habitat types was surveyed, including Acer campestre L., Corylus avellana L., Populus nigra L., Populus x canadensis Moench, Quercus robur L., Ulmus minor Mill., Robinia pseudoacacia L., Tilia sp.

For the study of the epiphytic lichen biota of woodlands and plantations in the lower Ticino River valley, in each selected site a $200 \mathrm{~m}$ long transect was randomly placed along an already existing trail crossing the woodland patch. At both ends and in the central point of the transect, epiphytic lichens were recorded on three randomly selected trees chosen at a distance of at least $10 \mathrm{~m}$ from the path. Nine trees per transect were sampled, for a total of 405 trees. Lichen occurrences were sampled in an area of $20 \times 200 \mathrm{~cm}$ on the northern and southern sides of the trunks, starting from the ground level. The sampled tree species was Quercus robur in both the woodland types and Populus x canadensis. in poplar plantations. In addition, scattered observations on the other main trees Carpinus betulus in well-preserved woodlands, Robinia pseudoacacia in degraded woodlands - and on dead wood (logs, stumps) were collected and are reported in the notes to the floristic list.
In spite of the heterogeneity of the sampling methods, the gathered data provide a fairly reliable, albeit not exhaustive overview on the epiphytic lichen biota occurring in the surveyed habitats.

Fieldwork was carried out in 2019. Easily recognizable species were identified in the field, while specimens of other taxa were collected and identified in the laboratory (Nimis \& Martellos, 2012). All collected specimens are preserved in the personal herbarium of the senior author.

The nomenclature follows Nimis \& Martellos (2020).

\section{Characterization of the lichen biota}

Spectra were computated for growth forms, photobionts, main reproduction strategy, ecological indices and poleotolerance. Data were retrieved from the database ITALIC (Nimis \& Martellos, 2020).

Growth forms include leprose, crustose, squamulose, foliose and fruticose lichens. Photobionts include chlorococcoid and trentepohlioid green algae. Main reproduction strategies include sexual reproduction, asexual reproduction by means of isidia and asexual reproduction by means of soredia.

Ecological indices (see Nimis, 2016) indicate ecological requirements of each species on an ordinal scale from 1 to 5 for the following features: substrate $\mathrm{pH}(1=$ very acidophytic; 2 = acidophytic; 3 = acidophytic to subneutrophytic; $4=$ slightly basiphytic; $5=$ basiphytic $)$, light $(1$ $=$ very skiophytic; $2=$ skiophytic; $3=$ moderately photophytic; $4=$ photophytic; $5=$ very photophytic), moisture ( 1 = hygrophytic; 2 = rather hygrophytic; $3=$ mesophytic; $4=$ rather xerophytic; $5=$ xerophytic) and eutrophication $(1=$ anitrophytic; 2 = slightly nitrophytic; $3=$ rather nitrophytic; 4 = nitrophytic; 5 = very nitrophytic).

The poleotolerance index indicates the tendency of each species to occur in sites with different degrees of human disturbance on an ordinal scale from 3 to 0 , as follows: $3=$ species occurring also in heavily disturbed areas; $2=$ species occurring also in moderately disturbed areas; $1=$ species mostly occurring in natural or semi-natural habitats; $0=$ species exclusive of old trees in ancient, undisturbed forests.

\section{RESULTS \\ Floristic list}

The complete floristic list includes 38 taxa, among which 10 never reported before from the Ticino river valley (Gheza et al., 2019): Anisomeridium polypori, Athallia cerinella, Blastenia ferruginea, Coenogonium pineti, Diarthonis spadicea, Graphis pulverulenta, Lecania cyrtellina, Lecanora expallens, Lepraria finkii, Pseudoschismatomma rufescens. Furthermore, 5 taxa are new to the Padanian ecoregion (Nimis 2016; Nimis \& Martellos 2020): Anisomeridium polypori, Coenogonium pineti, Diarthonis spadicea, Graphis pulverulenta, Opegrapha vermicellifera. Graphis pulverulenta and Lecania cyrtellina are new to Lombardy. Anisomeridium polypori, Diarthonis spadicea, Lecanora expallens and Pseudoschismatomma rufescens are reported from Lombardy for the second time. 
Tab. 1 - The 45 sites in which epiphytic lichens were surveyed. Site number, locality, municipality, coordinates (UTM WGS84 system, zone 32T) and mean altitude above the sea level are reported. / I 45 siti in cui sono stati rilevati i licheni epifiti. Sono riportati il numero del sito, la località, il comune, le coordinate (sistema UTM WGS84, zona 32T) e l'altitudine media sul livello del mare.

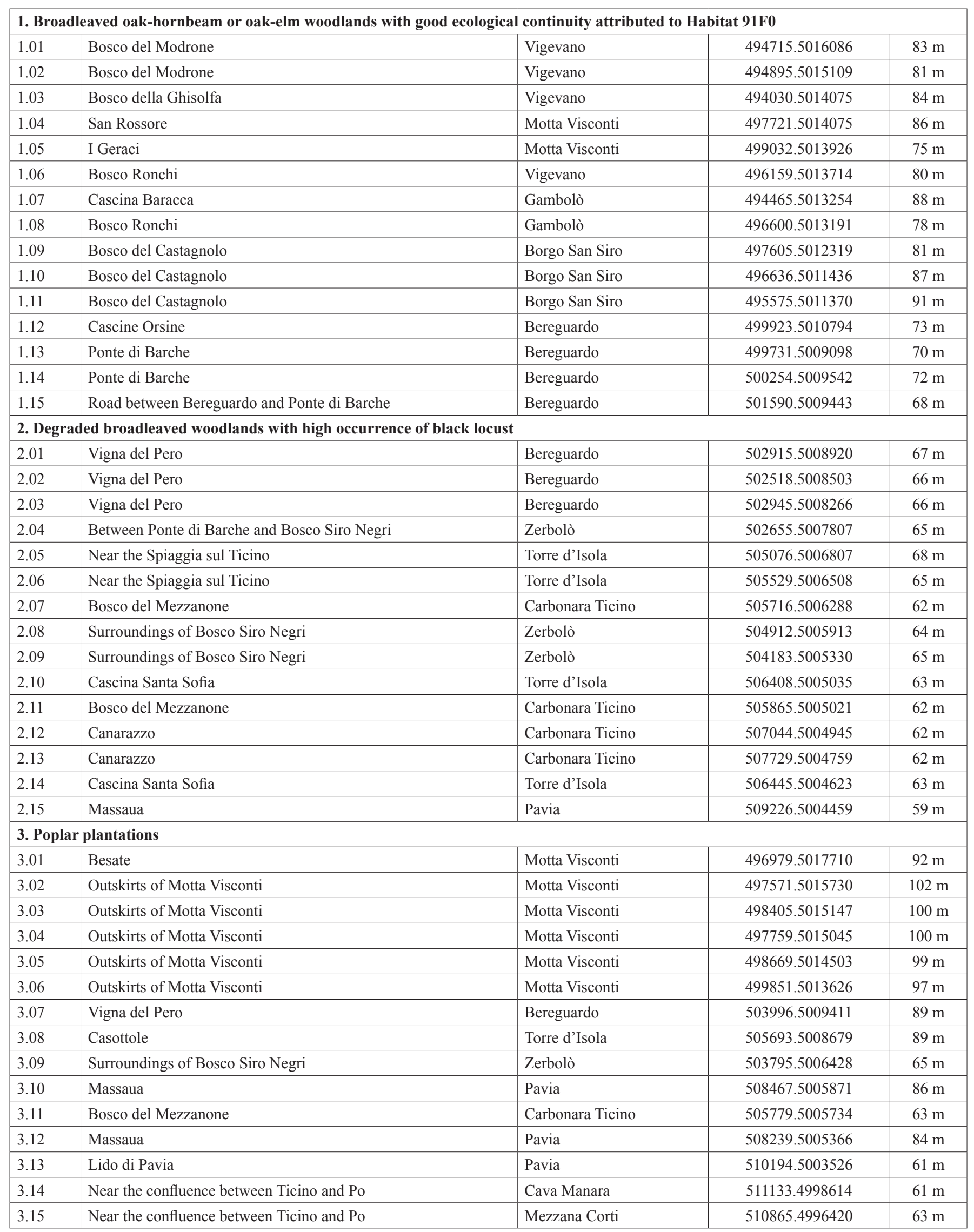




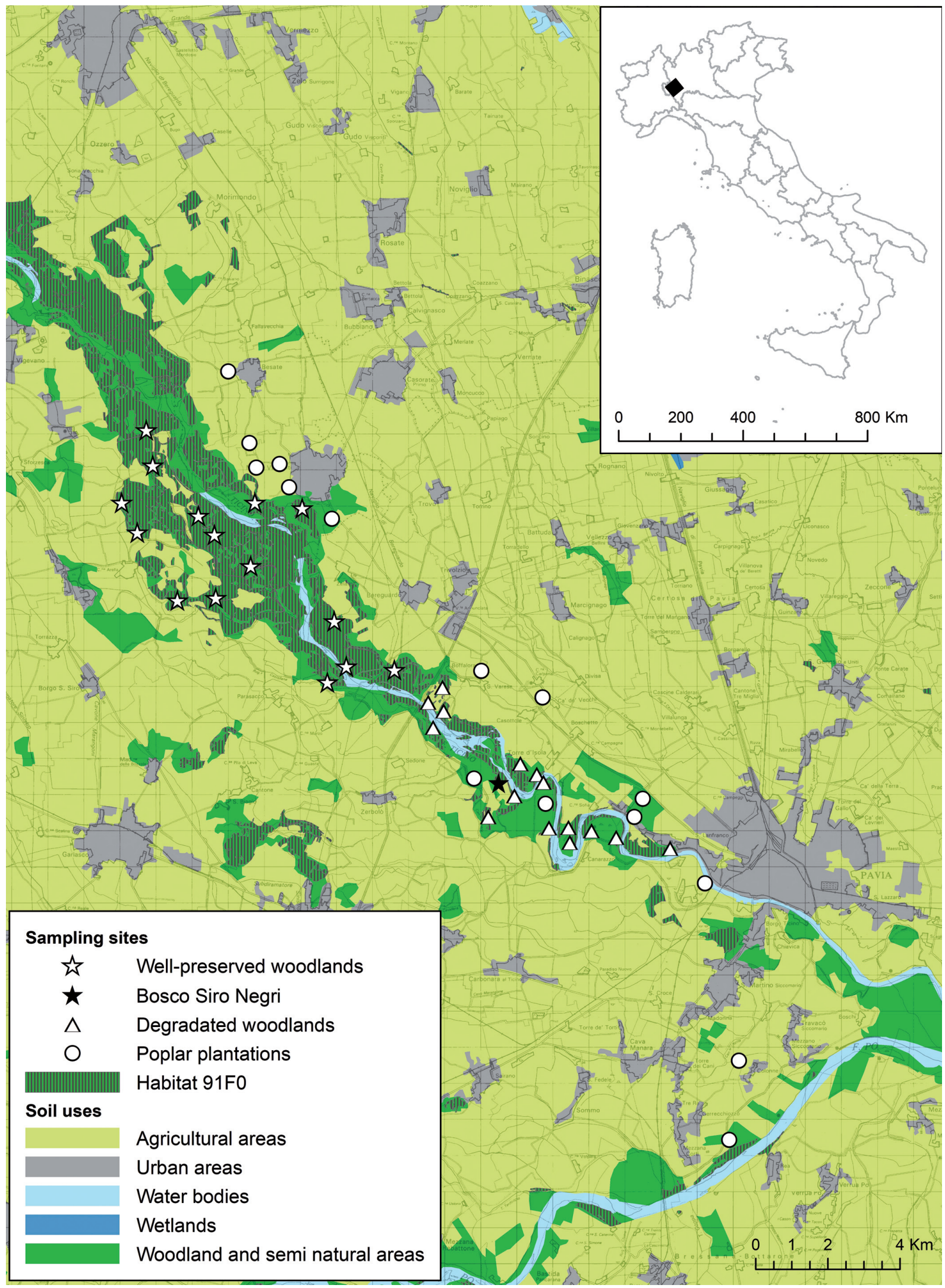

Fig. 1 - The study area, corresponding to the lower Ticino River valley. The "Bosco Siro Negri" Integral Nature State Reserve is indicated with a black star, the 15 well-preserved woodlands with white stars, the 15 degraded woodlands with white triangles and the 15 poplar plantations with white circles. Patches of vegetation attributed to Habitat $91 \mathrm{~F} 0$ are highlighted with a vertical line pattern. / L'area di studio, corrispondente alla bassa valle del Ticino. La Riserva Naturale Integrale Statale "Bosco Siro Negri” è indicata con una stella nera, i 15 boschi ben conservati con stelle bianche, i 15 boschi degradati con triangoli bianchi e i 15 pioppeti con cerchi bianchi. Le aree con vegetazione attribuita all'Habitat 91F0 sono evidenziate con una trama a linee verticali. 
In the "Bosco Siro Negri" Reserve, 27 taxa were found: 12 in the core riparian forest fragment (2 exclusively), 24 in the surrounding woods ( 8 exclusively), and 12 in the surrounding poplar plantations ( 2 exclusively). In the core, lichen diversity is differentiated according to the position of the species on the trees: only four species, which can be considered forest specialists, have been recorded on tree boles within $2.5 \mathrm{~m}$ from the ground, whereas the other eight species occurred only on branches and twigs fallen from the highest part of the tree canopy. On the boles, the most widespread species is Lepraria finkii, followed by Opegrapha vermicellifera, while Diarthonis spadicea and Coenogonium pineti are much rarer, both occurring only on a few trees. In the poplar plantations, lichen diversity was higher also thanks to the scattered occurrence among the poplar lines of oak and black locust trees - which hosted some species absent from poplar trunks - while the richest habitat was represented by degraded woodlands, but in both these habitat types forest specialists were missing.

Overall, the floristic list of the lower Ticino River valley includes 32 taxa. Only 13 taxa (6 exclusively) were found within well-preserved oak-hornbeam and oak-elm woods, whereas 21 taxa (4 exclusively) were found in degraded woodlands and 18 taxa (7 exclusively) in poplar plantations.

The annotated floristic list is reported below. Species new to the Ticino River valley (Gheza et al., 2019) are marked with *, species new to Lombardy are marked with **, redlisted species (Nascimbene et al., 2013) are marked with \#.

Amandinea punctata (Hoffm.) Coppins \& Scheid. Bosco Siro Negri: in the surrounding woodlands, on Tilia sp.; in poplar plantations, on Populus sp.

\section{* Anisomeridium polypori (Ellis \& Everh.) M.E.Barr} Site 2.10

Arthonia radiata (Pers.) Ach.

Sites 2.03, 2.07, 3.01, 3.06, 3.14.

* Athallia cerinella (Nyl.) Arup, Frödén \& Søchting Sites 3.01, 3.02, 3.03, 3.04, 3.05.

Athallia pyracea (Ach.) Arup, Frödén \& Søchting Bosco Siro Negri: in poplar plantations, on Populus sp. Sites 3.01, 3.02, 3.03, 3.04, 3.05, 3.06, 3.07, 3.08, 3.09, $3.10,3.11,3.12,3.14,3.15$.

\section{* Blastenia ferruginea (Huds.) A.Massal.}

Site 3.03.

Candelaria concolor (Dicks.) Stein

Bosco Siro Negri: in the core forest fragment, only on twigs fallen to the ground from the canopy, on Quercus robur; in the surrounding woodlands, on Populus nigra, Quercus robur, Robinia pseudoacacia, Tilia sp.; in poplar plantations, on Populus sp., Quercus robur.

Sites 1.01, 1.02, 1.07, 1.09, 2.01, 2.02, 2.04, 2.06, 2.07, $2.08,2.10,2.12,2.13,2.14,2.15,3.01,3.02,3.03,3.04$, $3.05,3.07,3.09,3.11,3.12,3.13,3.15$.
Candelariella reflexa (Nyl.) Lettau

Bosco Siro Negri: in the surrounding woodlands, on Quercus robur, Robinia pseudoacacia, Tilia sp.; in poplar plantations, on Populus sp., Quercus robur.

Sites 1.01, 1.02, 1.03, 2.01, 2.02, 2.04, 2.06, 2.07, 2.09, 2.10, 2.11, 2.13, 2.14, 3.01, 3.02, 3.04, 3.05, 3.07, 3.09, $3.11,3.12$.

Catillaria nigroclavata (Nyl.) J.Steiner

Bosco Siro Negri: in the surrounding woodlands, on Populus sp.; in poplar plantations, on Populus sp.

Sites 1.09, 2.10, 2.11, 3.01, 3.02, 3.03, 3.04, 3.05, 3.06, 3.07, 3.09, 3.10, 3.11, 3.13.

Cladonia coniocraea (Flörke) Spreng.

Bosco Siro Negri: in the surrounding woodlands, on Quercus robur.

Sites 1.04, 2.09.

It was often observed on stumps and logs in both wellpreserved and degraded woodlands (sites 1.01, 1.02, 1.03, $1.06,1.09,1.10,1.11,2.01,2.10)$.

Cladonia fimbriata (L.) Fr.

Bosco Siro Negri: in the surrounding woodlands, on Tilia sp. Sites 1.02, 1.03, 1.06, 1.10, 2.14.

It was often observed on stumps and logs in both wellpreserved and degraded woodlands (sites 1.01, 1.02, 1.03, $1.06,1.09,1.10,1.11,1.14,1.15,2.01,2.05,2.10)$.

Cladonia squamosa Hoffm.

Sites 1.01, 1.04.

It was observed also on stumps and $\operatorname{logs}$ (sites 1.01, 1.04).

* Coenogonium pineti (Ach.) Lücking \& Lumbsch Bosco Siro Negri: in the core forest fragment, on Quercus robur.

Sites 2.01, 2.05.

*\# Diarthonis spadicea (Leight.) Frisch, Ertz, Coppins \& P.F.Cannon

Bosco Siro Negri: in the core forest fragment, on Quercus robur.

Sites 1.01, 1.02, 1.05, 1.09, 1.10, 1.13.

Flavoparmelia caperata (L.) Hale

Bosco Siro Negri: in poplar plantations, on Quercus robur.

** Graphis pulverulenta (Pers.) Ach.

Site 1.09.

This species is uncommon on oak, but it was observed more frequently in well-preserved woodlands on Carpinus betulus (sites 1.02, 1.03, 1.07, 1.09, 1.10).

\section{Hyperphyscia adglutinata (Flörke) H. Mayrhofer \& Poelt}

Bosco Siro Negri: in the core forest fragment, only on twigs fallen to the ground from the canopy, on Quercus robur; in the surrounding woodlands, on Quercus robur; in poplar plantations, on Populus $s p$. 
Sites $2.02,2.05,2.06,2.07,2.08,2.10,2.12,2.13,2.15$, $3.02,3.04,3.05,3.09,3.11,3.12$.

Lecania cyrtella (Ach.) Th. Fr.

Sites 3.01, 3.02, 3.03, 3.04, 3.05, 3.06, 3.07, 3.08, 3.10, $3.13,3.14,3.15$.

** Lecania cyrtellina (Nyl.) Sandst.

Sites 3.02, 3.05, 3.06, 3.10, 3.11, 3.14.

Lecania naegelii (Hepp) Diederich \& van den Boom

Sites 3.10 .

\section{Lecanora chlarotera Nyl.}

Bosco Siro Negri: in the core forest fragment, only on twigs fallen to the ground from the canopy, on Quercus robur; in the surrounding woodlands, on Quercus robur; in poplar plantations, on Populus $s p$.

Sites 2.07, 2.10, 3.02, 3.05, 3.11, 3.12, 3.15.

\section{* Lecanora expallens Ach.}

Bosco Siro Negri: in the surrounding woodlands, on Quercus robur, Robinia pseudoacacia, Tilia sp.

Sites 1.02, 1.03, 1.05, 1.06, 1.08, 1.09, 2.01, 2.02, 2.03, 2.04, 2.05, 2.06, 2.07, 2.08, 2.10, 2.11, 2.13, 2.14.

Lecidella elaeochroma (Ach.) M.Choisy

Bosco Siro Negri: in the core forest fragment, only on twigs fallen to the ground from the canopy, on Quercus robur; in the surrounding woodlands, on Quercus robur, Robinia pseudoacacia.

Sites 2.12, 3.01, 3.03, 3.14, 3.15.

* Lepraria finkii (B. de Lesd.) R.C.Harris

Bosco Siro Negri: in the core forest fragment, on Acer campestre, Corylus avellana, Quercus robur, Robinia pseudoacacia, Ulmus minor; in the surrounding woodlands, on Populus nigra, Quercus robur.

Sites 1.01, 1.02, 1.03, 1.04, 1.05, 1.06, 1.07, 1.08, 1.09, $1.10,1.11,1.12,1.13,1.14,1.15,2.01,2.04,2.05,2.08$, $2.09,2.10,2.11,2.13,2.15$.

Melanelixia subaurifera (Nyl.) O. Blanco, A. Crespo, Divakar, Essl., D. Hawksw. \& Lumbsch

Bosco Siro Negri: in the surrounding woodlands, on Quercus robur.

Myriolecis hagenii (Ach.) Sliwa, Zhao Xin \& Lumbsch Sites 3.01, 3.03, 3.04, 3.05, 3.06, 3.08, 3.10, 3.11, 3.12, $3.13,3.14$.

\section{Normandina pulchella (Borrer) Nyl}

Site 1.03 .

Observed also on logs (Site 1.03).

Opegrapha vermicellifera (Kunze) J.R.Laundon

Bosco Siro Negri: in the core forest fragment, on Acer campestre, Corylus avellana, Populus nigra, Quercus robur, Robinia pseudoacacia, Ulmus minor; in the surrounding woodlands, on Populus nigra, Quercus robur.
Sites 1.06, 1.07, 1.08, 1.09, 1.10, 1.11, 1.12, 1.14, 1.15, 2.01, 2.04, 2.08, 2.10, 2.15.

Fertile specimens were observed in a few well-preserved woodlands (Bosco Siro Negri core woodland and sites $1.07,1.12,1.14,1.15)$.

Parmelia sulcata Taylor

Bosco Siro Negri: in the core forest fragment, only on twigs fallen to the ground from the canopy, on Quercus robur; in the surrounding woodlands, on Quercus robur, Tilia sp.

Sites 2.10, 2.12.

Parmelina tiliacea (Hoffm.) Hale

Bosco Siro Negri: in the surrounding woodlands, on Quercus robur.

Parmotrema perlatum (Ach.) M. Choisy

Bosco Siro Negri: in the surrounding woodlands, on Quercus robur.

Phaeophyscia orbicularis (Neck.) Moberg

Bosco Siro Negri: in the surrounding woodlands, on Populus sp.; in poplar plantations, on Populus sp.

Sites 2.07, 2.11, 2.12, 2.15, 3.01, 3.03, 3.05, 3.07, 3.08, $3.09,3.10,3.11,3.12,3.14,3.15$.

Phlyctis argena (Spreng.) Flot.

Bosco Siro Negri: in the surrounding woodlands, on Robinia pseudoacacia.

Physcia adscendens H. Olivier

Bosco Siro Negri: in the core forest fragment, only on twigs fallen to the ground from the canopy, on Quercus robur; in the surrounding woodlands, on Populus nigra, Quercus robur, Robinia pseudoacacia, Tilia sp.; in poplar plantations, on Populus sp., Quercus robur.

Sites $2.02,2.04,2.05,2.06,2.07,2.08,2.10,2.12,2.13$, $2.14,3.01,3.02,3.03,3.04,3.05,3.06,3.07,3.08,3.09$, $3.10,3.11,3.12,3.13,3.14,3.15$.

Physconia grisea (Lam.) Poelt

Bosco Siro Negri: in the core forest fragment, only on twigs fallen to the ground from the canopy, on Quercus robur; in the surrounding woodlands, on Populus sp., Robinia pseudoacacia, Tilia sp.; in poplar plantations, on Quercus robur.

Sites 2.10, 2.12, 3.09, 3.11.

* Pseudoschismatomma rufescens (Pers.) Ertz \& Tehler Bosco Siro Negri: in the surrounding woodlands, on Quercus robur, Robinia pseudoacacia; in poplar plantations, on Quercus robur, Robinia pseudoacacia.

Sites 1.04, 1.05, 1.06, 1.08, 1.10, 1.11, 1.13, 1.14, 2.01, $2.02,2.03,2.06,2.07,2.10,2.13,2.14,2.15$.

Observed frequently in well-preserved woodlands also on Carpinus betulus (sites 1.01, 1.03, 1.04, 1.06, 1.07, 1.09, $1.10,1.11,1.12,1.13,1.14,1.15)$ and less frequently in degraded woodlands on Robinia pseudoacacia (sites 2.04, $2.07,2.08,2.09,2.13)$. 
Punctelia subrudecta (Nyl.) Krog

Bosco Siro Negri: in the surrounding woodlands, on Quercus robur, Tilia sp.

Site 2.07 .

Xanthoria parietina (L.) Th. Fr.

Bosco Siro Negri: in the core forest fragment, only on twigs fallen to the ground from the canopy, on Quercus robur; in the surrounding woodlands, on Populus sp., Quercus robur, Robinia pseudoacacia, Tilia sp.; in poplar plantations, on Populus $s p$.

Sites 2.02, 2.06, 2.07, 2.10, 2.11, 2.12, 2.13, 2.15, 3.01, $3.02,3.03,3.04,3.05,3.06,3.07,3.08,3.09,3.10,3.11$, $3.12,3.13,3.14,3.15$.

\section{Characterization of the lichen biota}

Spectra referred to growth forms, photobionts, reproduction strategy, ecological indices (substrate $\mathrm{pH}$, light, moisture, eutrophication) and poleotolerance are reported in Tab. 2.

In the "Bosco Siro Negri" the distinction of the lichen biota across the three habitat types is quite clear for all the considered features. Only leprose and crustose species occur in the core woodland area, while growth forms are more differentiated in the surrounding woodlands and poorer again, but with a different pattern, in the poplar plantations. Species with a trentepohlioid photobiont dominate in the core woodland, while they decrease in the surrounding woodlands and are completely missing in poplar plantations; there, only species with chlorococcoid photobionts occur. The dominant reproduction strategy is mainly sexual in the core woodland, mainly asexual by means of soredia in the other two habitat types. The core woodland hosts more acidophytic, moderately skiophytic, hygrophytic to mesophytic and anitrophytic species, whereas poplar plantations host mainly subneutrophytic, photophytic, mesophytic to slightly xerophytic and moderately to strongly nitrophytic species. Poleophobic species are more represented in the core woodland, whereas poleotolerant species dominate in poplar plantations. Degraded woodlands show mostly an intermediate situation.

In the three habitats surveyed in the lower Ticino River valley, the situation is overall similar, except for growth forms and photobionts. In fact, growth forms are more differentiated in well-preserved woodlands, while they decrease to only two - crustose and foliose - in poplar plantations. The most represented photobiont is always chlorococcoid, but the percentage of species with trentepohlioid algae decreases evidently from well-preserved woodlands to poplar plantations. Reproduction strategies are more differentiated in well-preserved woodlands, and asexual reproduction dominates in both woodland types, whereas in poplar plantations species which reproduce mainly sexually dominate the spectrum. Well-preserved woodlands host more acidophytic, moderately skiophytic, hygrophytic to mesophytic and anitrophytic species, whereas poplar plantations host mainly subneutrophytic, photophytic, xerophytic and moderately to strongly nitrophytic species. Poleophobic species are more represented in well-preserved woodlands, while poleotolerant species dominate in poplar plantations. Degraded woodlands al- ways show an intermediate situation, and are richer in species than both well-preserved woodlands and poplar plantations.

\section{DISCUSSION}

\section{Lichens of the "Bosco Siro Negri" Integral Nature State Reserve}

Within the core of the "Bosco Siro Negri" Integral Reserve, only four epiphytic lichen species were found on the boles: Lepraria finkii and Opegrapha vermicellife$r a$ were the most widespread, while Diarthonis spadicea and Coenogonium pineti were much rarer. Three of them can be considered forest specialists, being anitrophytic, moderately skiophytic and mesophytic, whereas $L$. finkii has a slightly broader ecological amplitude. An additional eight nitro- and photophytic species were recorded on twigs fallen to the ground from the canopy, indicating that ecological conditions are very different between the understory and the canopies. This probably happens because the forest fragment is very small, and, even being able to maintain forest-like conditions in the understory, it is not large enough to do the same in the crowns, which are influenced by the surrounding agricultural landscape.

This situation is overall similar to that reported by Härdtle et al. (1996) from oak-elm forests in the Elbe floodplain, where the most frequent species were Lepraria incana (L.) Ach. on the trunks and Lecanora conizaeoides Cromb. on the lower branches, generally being the only occurring species. Furthermore, Härdtle et al. (1996) also reported the occurrence of photo- and nitrophytic species (i.e. Amandinea punctata, Parmelia sulcata, Physcia adscendens, Physcia tenella (Scop.) DC., Phaeophyscia orbicularis, Polycauliona candelaria (L.) Frödén, Arup \& Søchting) in the crown twigs, but they found there also more interesting species (i.e. Platismatia glauca (L.) W.L. Culb. \& C.F. Culb., Pseudevernia furfuracea (L.) Zopf), which did not occur in our study area, probably due to both the different climate and the severely compromised lichenological situation of the Po Plain (cf. Nimis, 1993).

The species recorded in the surrounding woodlands and poplar plantations are generally common and widespread in the Ticino river valley (Valcuvia Passadore, 2002a, 2002b; Gheza et al., 2019) and, in most cases, in the whole Po Plain (Nimis \& Martellos, 2020).

In short, the situation recorded in the "Bosco Siro Negri" Reserve is representative on a smaller scale of the same situation existing on a larger scale in the rest of the lower Ticino River valley (see next paragraphs).

\section{Lichens of woodlands and plantations in the lower Ticino River valley}

Woodlands with higher naturality were poorer in species, but overall hosted rarer species and often forest specialists. Habitat 91F0 is considered poor in lichen species of conservation concern in Italy (Nascimbene et al., 2013); indeed, the only red-listed species recorded in this survey was Diarthonis spadicea, which was assessed as NT (near-threatened) by Nascimbene et al. 
Tab. 2 - Spectra referred to growth forms, photobionts, sexual strategy, ecological (substrate $\mathrm{pH}$, light, moisture, eutrophication) and poleotolerance indices. The first three columns report data from "Bosco Siro Negri" (1: core woodland; 2: surrounding woodlands; 3: poplar plantations), the last three report data from the 45 sites surveyed in the study area (1: well-preserved woodlands; 2 : degraded woodlands; 3: poplar plantations). In the core woodland of "Bosco Siro Negri" only the species recorded on the boles have been considered, for uniformity with the other habitats, in which lichens on twigs and branches were not surveyed. / Spettri riferiti a forme di crescita, fotobionti, strategia sessuale, indici ecologici ( $\mathrm{pH}$ del substrato, luce, umidità, eutrofizzazione) e di poleotolleranza. Le prime tre colonne riportano $\mathrm{i}$ dati del "Bosco Siro Negri" (1: nucleo boschivo ben conservato; 2: boschi circostanti; 3: pioppeti), le ultime tre riportano i dati dei 45 siti censiti nell' area di studio (1: boschi ben conservati; 2: boschi degradati; 3: pioppeti). Nel nucleo boschivo del "Bosco Siro Negri" sono state considerate solo le specie registrate sui tronchi, per uniformità con gli altri habitat, nei quali non sono stati rilevati licheni su rametti e rami.

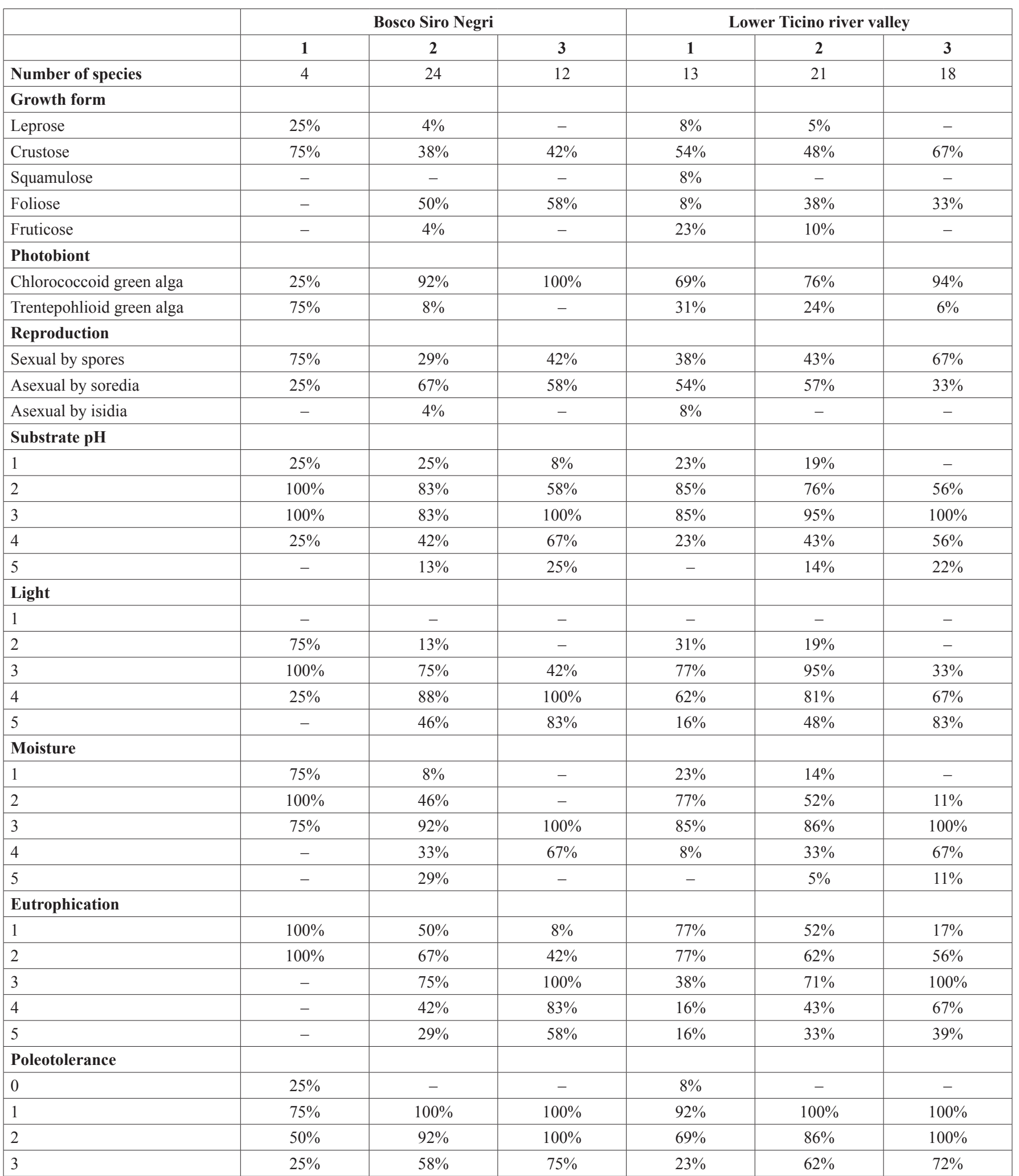


(2013). Lepraria finkii was the most widespread and abundant species in well-preserved woodlands. A lichen community dominated by Lepraria spp. (Leprarietum incanae James, Hawksworth \& Rose 1977) is often the "climax" epiphytic lichen community in dense and old oak-dominated woods, since the high cover of the canopy and the shrubs of the understory foster the transition of epiphytic communities toward this skio- and hygrophitic association (Prigodina Lukošienė \& Naujalis, 2006). However, where habitat quality is high and environmental conditions are stable and favourable to typical species, also communities dominated by Opegrapha vermicellifera or Diarthonis spadicea can last (Bricaud, 2010; Van Haluwyn, 2010). The former is typical of old, dense, shaded forests, where it develops in moist sites protected from direct rainfall (Berger \& Türk, 1995; Berger \& Priemetzhofer, 2010; Bricaud, 2010). The latter is typical of moist old forests, well-lit but without direct irradiation (Van Haluwyn, 2010). Such communities have been generally reported as developing in the lowermost parts of the boles, or even being limited to the roots (Berger \& Türk, 1995; Berger \& Priemetzhofer, 2010; Van Haluwyn, 2010), but in our study area they occurred in some cases up to $2.5 \mathrm{~m}$ from the ground. Lichen communities recorded in degraded woodlands and poplar plantations can be referred to Parmelion and Xanthorion respectively (ANPA, 2001) and have a low conservation value.

Overall, there was a clear pattern in growth forms, photobiont and ecology gradually changing from wellpreserved woodlands to poplar plantations. Woodlands were more diverse in both growth forms and photobionts, while in poplar plantations the situation was poorer and more homogeneous. Species with a trentepohlioid photobiont were more abundant, even dominating the epiphytic community in some cases, in well-preserved woodlands. This is due to the fact that such woodlands have a higher cover of the canopy, and trentepohlioid algae have their photosynthetic optimum in shaded, moist and warm conditions (Jüriado \& Paal, 2019). However, lichens with a trentepohlioid photobiont are rare in areas with intensive land use (Stofer et al., 2006), and this is probably the reason for their low overall richness in the study area. On the other hand, they are expected to increase their range and become more widespread due to the rising temperatures of climate change, as reported from the Netherlands for some species recorded also by us, i.e. Anisomeridium polypori, Coenogonium pineti, and Diarthonis spadicea (Aptroot \& van Herk, 2007).

The communities of well-preserved woodlands were less photophytic, more hygrophytic and anitrophytic, whereas the communities of poplar plantations were strongly photophytic, xerophytic and nitrophytic, the communities of degraded woodlands having an intermediate ecology. The communities of well-preserved woodlands were also more acidophytic, since the bark $\mathrm{pH}$ of Quercus is acidic, whereas the bark of Populus is subneutral and in plantations its $\mathrm{pH}$ is often even higher due to eutrophication caused by atmospheric deposition from neighbouring agricultural areas (ANPA, 2001). Also in this case, the degraded woodlands stood in an intermediate situation, being more open than well-preserved wo- odlands but more closed than plantations. This situation results in a few forest specialists being limited to wellpreserved woodlands, with degraded woodlands hosting a richer lichen biota due to their intermediate conditions and poplar plantations hosting chiefly generalist, pioneer and fast-developing species.

\section{Noteworthy species}

Diarthonis spadicea and Opegrapha vermicellifera are the two most interesting species among those found in well-preserved woodlands. Diarthonis spadicea, the only red-listed species (NT) (Nascimbene et al., 2013), is an indicator of good habitat quality and ecological continuity in broadleaved woodlands dominated by Quercus robur, also considered an old-growth indicator by some authors (Printzen et al., 2002; Ikauniece et al., 2012; Moisejevs, 2016; Štikāne et al., 2017). The only previous record from Lombardy dates back to the middle of the $19^{\text {th }}$ century from the hills surrounding Como (Anzi, 1860). Opegrapha vermicellifera is considered an indicator of primeval lowland forests (Czyżewska \& Cieśliński, 2003; Wieczorek, 2018) and of good ecological continuity in broadleaved forests as well (Bricaud, 2010). It seems to be bound to stands located near rivercourses (Nimis, 1993). In some sites, always in well-preserved stands, the species was found fertile, which is rare and likely to imply a good environmental quality (Wieczorek, 2018). The only two previous records from Lombardy are recent, from the upper Ticino river valley (Valcuvia Passadore et al., 2002a, 2002b) and Bosco della Fontana (Valcuvia Passadore \& Truzzi, 2008). In the study area, both these species occurred only in well-preserved, dense oak woodlands, often near to the main rivercourse of the Ticino, to its secondary canals or to oxbow lakes. Their occurrence can be considered as a further confirmation of a relatively good quality of those woodland stands.

Graphis pulverulenta, recorded as well in such woodlands, was never reported before from Lombardy, since the citation reported by Nimis (2016) is likely due to a misinterpretation of the map by Neuwirth \& Aptroot (2011), who actually reported the species from Piedmont and not from Lombardy, as inferrable from the text. Since the species has been confirmed only recently as separated from Graphis scripta (L.) Ach. (Neuwirth \& Aptroot, 2011), some older records of the latter could instead be referred to Graphis pulverulenta (see Gheza et al., 2019), which occurs also in the upper river valley (Gheza, unpubl. data).

Anisomeridium polypori and Coenogonium pineti are the two most interesting species among those found only or mainly in degraded woodlands. Anisomeridium polypori was reported before only once from Lombardy, based on a herbarium specimen collected in the Adamello Natural Park (UPS-L-166802, cited by Nimis, 2016). The record reported here widens its range in the region down to the lowlands. Coenogonium pineti was found not only in low-quality groves, but also in the well-preserved core woodland of "Bosco Siro Negri". In spite of having been reported rarely from Lombardy (Anzi, 1860; Stizenberger, 1882; Gheza, 2018), this species is probably more 
widespread not only in the woodlands of the Ticino River valley, but also in the whole region, but it can be easily overlooked when sterile. Similarly, also Lecanora expallens, reported previously only once from Lombardy (Stofer, 2006), was found in several study sites, especially in open woodlands, suggesting that it can be more widespread in the whole region.

Pseudoschismatomma rufescens occurred quite frequently in both woodland types, and occurred also in some poplar plantations, but never on poplar, therefore only when the plantations hosted rows of different tree species (i.e. Quercus robur, Robinia pseudoacacia). The only previous record of this species in Lombardy dates back to the early 1900s from the surroundings of the upper Ticino River valley (Cozzi, 1917). In some forests of central Europe this species is even rarer than Diarthonis spadicea (Cieśliński, 2000); however, in Italy it is not considered a species of conservation concern and was not assessed in the Red List (Nascimbene et al., 2013). Based on recent collections in the Orobic Prealps (Gheza, unpubl. data), also this species is probably more widespread in broadleaved forests of Lombardy, from the lowlands to the montane belt.

The poplar plantations hosted chiefly common and widespread species, but one of them, Lecania cyrtellina, had never been reported before from Lombardy. This species can be easily confused with the very similar Lecania cyrtella, which is widespread in poplar plantations; this suggests that perhaps also L. cyrtellina can be more widespread, at least in this synanthropic habitat. Similarly, also Lecania naegelii, in spite of having been reported rarely from Lombardy (Anzi, 1860; Valcuvia Passadore et al., 2002a, 2002b), could be more widespread.

Lepraria finkii was the only Lepraria species recorded, and it was frequently occurring and abundant in wellpreserved woodlands, but also quite frequently occurring in degraded woodlands. The high occurrence of this species, the fact that Lepraria incana was never found during these and other recent surveys in the river valley (Ghe$\mathrm{za}$, unpubl. data), and the fact that in literature records of $L$. incana from the same area TLC was never mentioned (therefore probably never used), suggest that most, if not all, of the old records of L. incana from the same area should probably be assigned to this species. More in general, all literature records of "Lepraria incana" from the Po Plain not based on TLC analyses should be verified, since this species has a narrower ecological amplitude and poleotolerance than L. finkii (Nimis, 2016), the study of secondary metabolites being indispensable to identify $L e$ praria species with certainty (Baruffo et al., 2006). This question deserves to be studied more deeply.

\section{CONCLUSIONS}

This research provided a first insight into the epiphytic lichen biota of the relict floodplain forest of the Po Plain and an accurate description of the lichens of the "Bosco Siro Negri" Integral Nature State Reserve, which is one of the best preserved remains of it. It is also a contribution to better understand relations between epiphytic lichens and Natura 2000 Habitats, which is an overlooked topic in Italy, unlike in other European countries (e.g. Moisejevs, 2016). Furthermore, we showed that also synanthropic habitats with little environmental value, like poplar plantations, can be interesting for floristic research, hosting previously unreported species.

Overall, the need for basic floristic research on the lichens of the Po Plain is highlighted by the fact that 10 taxa out of 38 ( $26 \%$ of the surveyed species) were never reported before from a well-studied area like the Ticino river valley, and species which are probably not rare in the whole of Lombardy (e.g. Coenogonium pineti, Lecania naegelii, Lecanora expallens, Pseudoschismatomma rufescens) have been reported only very rarely in the previous literature, in spite of the fact that this region is to date one of the richest in both lichenological papers and reported lichen taxa in Italy (Nimis, 2016). This highlights that new field investigations in unexplored or overlooked areas are crucial to widen knowledge of lichen biota and to get recent and reliable data which can be useful from the perspective of a first critical checklist of the lichen flora of Lombardy. Checklists can be a precious tool to plan both further investigations and conservation actions (e.g. Gheza et al., 2021).

\section{Acknowledgements}

This study was funded by the "Bosco Siro Negri" Integral Nature State Reserve and the "Ministero dell'Ambiente e della Tutela del Territorio e del Mare". We thank Prof. Helmut Mayrhofer (University of Graz) for helping with the identification of Lepraria specimens which needed TLC, Dr. Zeno Porro for helping in realizing the sampling design, Paola Tassone for helping in the fieldwork, Alida Piglia and Michael L. Sand for the revision of the English style.

GG, SA conceived the idea; SA, MB, FB contributed with expertise on the woodland habitats of the Ticino River Valley; GG carried out the fieldwork; GG, JN identified the specimens; MB realized the map; SA, FB provided funding to investigate lichens in the "Bosco Siro Negri" Integral Reserve; GG prepared the first draft and all the authors contributed to the final version of the manuscript.

\section{REFERENCES}

ANPA, 2001 - I.B.L. Indice di Biodiversità Lichenica. Manuali e Linee Guida 2/2001. ANPA, Roma.

Anzi M., 1860 - Catalogus lichenum quos in Provincia Sondriensi et circa Novum-Comum collegit et in ordinem systematicum digessit presbyter Martinus Anzi. Tipografia C. Franchi, Novi-Comi.

Aptroot A. \& van Herk C. M., 2007 - Further evidence of the effects of global warming on lichens, particularly those with Trentepohlia phycobionts. Environmental Pollution, 146 (2): 293-298.

Baruffo L., Zedda L., Elix J. A. \& Tretiach M., 2006 - A revision of the lichen genus Lepraria s. lat. in Italy. Nova Hedwigia, 83: 387-429.

Berger F. \& Priemetzhofer F., 2010 - Die Flechtenflora im Nationalpark Thayatal (Niederösterreich, Österreich). Wissenschaftliche Mitteilungen Niederösterreiches Landesmuseum, 21: 135-184.

Berger F. \& Türk., 1995 - Die Flechtenflora im unteren Rannatal (Mühlviertel, Oberösterreich, Österreich). Beiträge zur Naturkunde Oberösterreichs, 3: 147-216.

Biondi E. \& Baldoni M., 1994 - The climate and vegetation of Peninsular Italy. Colloques Phytosociologiques, 23: 675-721. 
Bricaud O., 2010 - Les lichens des forets de la region mediterraneenne francaise et leur relation avec la continuite ecologique des boisements. Rapport $W W F$, Marseille.

Brusa G., 2014 - Studio ecologico della componente briologica della Riserva Naturale "Bosco Siro Negri". Technical report.

Casarini P., Genoni P. \& Roella V., 1995 - La qualità dell'aria nel Parco Regionale Lombardo della Valle del Ticino. Monitoraggio dell'aria effettuato mediante analisi dei licheni. Consorzio Lombardo Parco della Valle del Ticino.

Castagneri D., Garbarino M. \& Nola P., 2013 - Host preference and growth patterns of ivy (Hedera helix L.) in a temperate alluvial forest. Plant Ecology, 214: 1-9.

Castaldini D., Marchetti M., Norini G., Vandelli V. \& Zuluaga Vélez M. C., 2019 - Geomorphology of the central Po Plain, Northern Italy. Journal of Maps, 15 (2): 780-787.

Castiglioni G. B. \& Pellegrini G. B., 2001 - Note illustrative della Carta Geomorfologica della Pianura Padana. Supplementi di Geografia Fisica e Dinamica Quaternaria, Supplemento IV. Comitato Glaciologico Italiano, Torino.

Cieśliński S., 2000 - Białe Ługi Reserve: a refuge of the forest lichen flora of the Góry Świetokrzyskie Mts. Fragmenta floristica et geobotanica Polonica, 45 (1-2): 485-492.

Cozzi C., 1917 - Manipolo di licheni della pianura milanese. Bullettino della Società Botanica Italiana, 1917 (4-5): 39-44.

Czyżewska K. \& Cieśliński S., 2003 - Porosty - wskazniki nizowych lasow puszczanskich w Polsce. Monographiae Botanicae, 91: 223239.

Delucchi C., 2005 - I licheni epifiti come indicatori dello stato di salute di boschi planiziali lombardi. Technical report.

Furlanetto D. (ed.), 2000 - Monitoraggio della qualità dell'aria mediante licheni nella Valle del Ticino. Consorzio Lombardo Parco della Valle del Ticino.

Gheza G., 2018 - Addenda to the lichen flora of the Ticino river valley (western Po Plain). Natural History Sciences, 5 (2): 3340.

Gheza G., Nicola S., Parco V. \& Assini S., 2019 - La diversità lichenica nella Valle del Ticino: conoscenze in continua evoluzione. Atti del $32^{\circ}$ Convegno della Società Lichenologica Italiana. Notiziario della Società Lichenologia Italiana, 32: 56.

Gheza G., Di Nuzzo L., Vallese C., Benesperi R., Bianchi E., Di Cecco V., Di Martino L., Giordani P., Hafellner J., Mayrhofer H., Nimis P. L., Tretiach M. \& Nascimbene J., 2021 - The lichens of the Majella National Park (Central Italy): an annotated checklist. Mycokeys, 78: 119-168

Härdtle W., Bracht H. \& Hobohm C., 1996 - Vegetation und Erhaltungszustand von Hartholzauen (Querco-Ulmetum Issl. 1924) im Mittelelbegebiet zwischen Lauenburg und Havelberg. Tuexenia, 16: $25-38$.

Ikauniece S., Brūmelis G. \& Kondratovičs T., 2012 - Naturalness of Quercus robur stands in Latvia, estimated by structure, species, and processes. Estonian Journal of Ecology, 61 (1): 64-81.

Jüriado I. \& Paal J., 2019 - Epiphytic lichen synusiae and functional trait groups in boreo-nemoral deciduous forests are influenced by host tree and environmental factors. Nordic Journal of Botany, 37 (1): e01939.

Moisejevs R., 2016 - Ķērpju indikatorsugu rokasgrāmata dabas pētniekiem. SIA "Estonian, Latvian \& Lithuanian Environment" \& University of Daugavpils.

Motta R., Nola P. \& Berretti R., 2009 - The rise and fall of the black locust (Robinia pseudoacacia L.) in the "Siro Negri" forest reserve (Lombardy, Italy): lessons learned and future uncertainties. Annals of Forest Science, 66: 410.

Nascimbene J., Nimis P. L. \& Ravera S., 2013 - Evaluating the conservation status of epiphytic lichens of Italy: a Red List. Plant Biosystems, 147 (4): 898-904.

Navati E., Pezzati M. L. \& Rossetti R., 1983 - Nota preliminare sulle condizioni pluviometriche della Valle del F. Ticino a sud del Lago Maggiore nel trentennio 1951-80. Atti dell'Istituto Geologico dell'Università di Pavia, 30 (1): 103-115.

Neuwirth G. \& Aptroot A., 2011 - Recognition of four morphologically distinct species in the Graphis scripta complex in Europe. Herzogia, 24 (2): 207-230.
Nimis P. L., 1993 - The lichens of Italy: an annotated catalogue. Monografie XII. Museo Regionale di Scienze Naturali di Torino.

Nimis P. L., 2016 - The Lichens of Italy. A Second Annotated Catalogue. EUT, Trieste.

Nimis P. L. \& Martellos S., 2012 - Materiali per una guida ai licheni epifiti d'Italia. Università degli Studi di Trieste. <http://dbiodbs. units.it/carso/chiavi_pub21?sc=120>

Nimis P. L. \& Martellos S., 2020 - ITALIC 6.0, The Information System on Italian Lichens. Università degli Studi di Trieste, Dipartimento di Scienza della Vita. $<$ http://italic.units.it> (Accessed on 9 December 2020).

Perracino M., 2010 - Atlante dei SIC della provincia di Pavia. Regione Lombardia e Fondazione Lombardia per l'Ambiente, Milano.

Prigodina Lukošienė I. \& Naujalis J. R., 2006 - Principal relationships among epiphytic communities on common oak (Quercus robur L.) trunks in Lithuania. Ekologija, 2: 21-25.

Printzen C., Halda J., Palice Z. \& Tønsberg T., 2002 - New and interesting lichen records from old-growth forest stands in the German National Park Bayerischer Wald. Nova Hedwigia, 74 (1-2): 25-49.

Roella V., 1999 - Licheni epifiti. In: Atlante della biodiversità nel Parco Ticino. Furlanetto D. (ed.). Consorzio Lombardo Parco della Valle del Ticino, Milano: 15-18.

Sartori F., 1984 - Les forêts alluviales de la basse vallée du Tessin (Italie du Nord). Colloques phytosociologiques, 9: 201-216.

Štikāne K., Brūmelis G., Piterāns A. \& Moisejevs R., 2017 - Epiphytic lichen diversity in broadleaved tree forests in Latvia. Acta Biologica Universitatis Daugavpiliensis, 17 (1): 123-132.

Stizenberger E., 1882 - Lichenes Helvetici eorumque stationes et distributio. Jahresbericht der St. Gallischen Naturwissenschaftlichen Gesellschaft, 22: 225-522.

Stofer S. (ed.), 2006 - Working Report ForestBIOTA. Epiphytic Lichen Monitoring. <http://www.forestbiota.org/docs/report lichens_20060503.pdf $>$

Stofer S., Bergamini A., Aragón G., Carvalho P., Coppins B. J., Davey S., Dietrich M., Farkas E., Kärkkäinen K., Keller C., Lökös L., Lommi S., Máguas C., Mitchell R., Pinho P., Rico V. J., Truscott A.-M., Wolseley P. A., Watt A. \& Scheidegger C., 2006 - Species richness of lichen functional groups in relation to land use intensity. The Lichenologist, 38 (4): 331-353.

Tomaselli R. \& Gentile S., 1971 - La riserva naturale integrale "Bosco Siro Negri" dell'Università di Pavia. Atti dell'Istituto Botanico e del Laboratorio Crittogamico dell'Università di Pavia, serie 6, 7: 41-70.

Valcuvia Passadore M. \& Truzzi A., 2008 - The epiphytic lichen flora of Bosco della Fontana. In: Canopy analysis and dynamic of a floodplain forest. Gianelle D., Travaglini D., Mason F., Minari E., Chirici G. \& Chemini C. (eds.). Cierre Edizioni, Verona: 79-87.

Valcuvia Passadore M., Brusa G., Chiappetta D., Delucchi C., Garavani M. \& Parco V., 2002a - Licheni. In: Atlante della Biodiversità nel Parco Ticino. Vol. 1: elenchi sistematici. Furlanetto D. (ed.). Consorzio Lombardo Parco della Valle del Ticino, Milano: 105-127.

Valcuvia Passadore M., Brusa G., Chiappetta D., Delucchi C., Garavani M. \& Parco V., 2002b - Licheni. In: Atlante della Biodiversità nel Parco Ticino. Vol. 2: monografie. Furlanetto D. (ed.). Consorzio Lombardo Parco della Valle del Ticino, Milano: 7-44.

Van Haluwyn C., 2010 - La sociologie des lichens corticoles en Europe depuis Klement (1955) et Barkman (1958). Essai de synthese. Bulletin de l'Association Francaise de Lichenologie, 35 (2): 1-128.

Verde S., Assini S. \& Andreis C., 2010 - Le Serie di Vegetazione della regione Lombardia. In: La Vegetazione d'Italia. Blasi C. (ed.). $P a-$ lombi \& Partner S.r.l., Roma.

Wieczorek A., 2018 - The lichen genus Opegrapha s. 1. in Poland: morphological variability, ecology and distribution. Monographiae Botanicae, 107.

Zocchi A., Casarini P., Genoni P., Guidetti L., Roella V., Borlandelli C. \& Stefanetti M. V., 1997 - Air quality monitoring, using epiphytic lichens, in some Northern-Italian areas (Lombardy and Piedmont). Lagascalia, 19 (1-2): 505-512. 